\title{
AMBRUS LÁSZLÓ
}

\section{SZEMELVÉNYEK AZ ELSŐ VILÁGHÁBORÚ ANGOL NYELVŰ HISTORIOGRÁFIÁJÁBÓL A 2000-ES ÉVEKBEN}

Az első világháború nemzetközi historiográfiája rendkívül széles vizsgálati szempontskálán mozog, különösen az ezredforduló környékétől kezdődően. Ennek újabb lökést adott a centenárium ötéves időszaka, minek eredményeként a 2014 és 2019 között eltelt évek során konferenciák százait rendezték, tanulmánykötetek, monográfiák és a folyóiratok tematikus számai pedig oly mértékben özönlöttek az érdeklődő olvasókra, hogy ember legyen a talpán, aki a teljes szakirodalommal meg képes birkózni. Ebben a historiográfiai jellegú tanulmányban magam is csak annyira vállalkozom, hogy egy rövid, de velős áttekintést nyújtsak, ami szándékom szerint lefedi az elmúlt két évtized „termésének" főbb irányvonalait, legkiemelkedőbb vagy legérdekesebb munkáit, ám közel sem ad teljes bibliográfiát az elmúlt húsz év során megjelent első világháborús témájú munkákról.

Nincs könnyű helyzetben az első világháborúval foglalkozó kutató, amikor a téma tengernyi szakirodalmát próbálja összegezni vagy éppen kijelölni belőle a kiemelésre leginkább érdemes darabokat. A témakörben megjelent művek óriási száma és a kutatási szempontok rendkívüli sokszínúsége miatt akár külön doktori disszertációk is készülhetnének a nagy háború angol nyelvű historiográfiájáról. A brit hadtörténet-kutatás „nagy öregjei”, John Keegan, ${ }^{1}$ Michael Howard ${ }^{2}$ vagy Martin Gilbert ${ }^{3}$ mind megírták a maguk "nagy háború"-összegzését, természetesen a frontokon zajló hadi eseményekre fókuszálva. Közülük Magyarországon Keegan a legismertebb, vaskos hadtörténelmi elemzései, melyeket talán legjellemzőbb kifejezéssel terjedelmes esszéknek nevezhetünk, igen népszerűek nemcsak a szakma, de az érdeklődő „laikus” közönség körében is. Az első és második világháborúval foglalkozó művei Magyarországon is több kiadást megéltek, többek között az Európa Kiadó gondozásában. ${ }^{4}$ Mindkettő meglehetősen kimerítően tárgyalja a világháborúk eseménytörténetét, nem hanyagolva el a hátország helyzetének bemutatását sem. Hiányosságaként viszont megemlítendő, hogy a Keegan-féle Első világháború fókuszpontja egyértelmúen és látványosan a nyugati fronton található, és viszonylag mostohán bánik a keleti és a balkáni front történéseivel. Ettől függetlenül a téma alapművének tekinthető, hiszen amellett, hogy átfogó képet nyújt a háború ese-

1 John Keegan, The First World War (London, 1998).

2 Michael Howard, The First World War (Oxford, 2002).

3 Martin Gilbert: The First World War. A Complete History (London, 1986).

4 John Keegan, Az első világháború (Budapest: Európa, 2010)., ill. uő: A második világháború. (Budapest: Európa, 2008). 
ményeiről, a Keegantől megszokott olvasmányos stílusban nemcsak a katonai események sorra vételét adja, hanem a gazdasági, társadalmi és politikai összefüggéseket is igyekszik - igaz, jóval rövidebben - összefoglalni.

Ralph James Quincy Adams, a Texas állambeli College Station városában található Texas A\&M University (erről az egyetemről még több ízben lesz szó a későbbiekben) történészének szerkesztésében 1990-ben megjelent a mára a fentiekhez hasonlóan klasszikusnak számító The Great War, 1914-1918 címú kitűnő tanulmánykötet. ${ }^{5} \mathrm{~A}$ kissé vékony, de annál jelentősebb kötetben brit és amerikai történészek a háború néhány fontos, kevésbé tárgyalt aspektusával foglalkoznak, mint például a katonák és a civilek viszonya a háborús Németországban, a brit légvédelem eredendő problémái, a kanadai háborús tapasztalatok vagy az Amerikai Expedíciós Erők logisztikai és utánpótlás-szervezési nehézségei. A kötet jelentősen meghaladta korát, hiszen már 1990-ben előrevetítette a 2000 -es évek színes, rendkívül gazdag tematikájú nagy háborúval foglalkozó kutatásait.

Immár a 2000-es évekbe érkezve, a háborúról átfogó képet nyújtó művek sorát gyarapította Gordon Corrigan 2003-ban megjelent múvével. A Mud, Blood, and Poppycock (Sár, vér és pipacs) címú kötet azonban jóval többet kínál egy újabb hadtörténeti összefoglalónál. ${ }^{6}$ Célja a brit társadalom széles köreiben a háborúval kapcsolatban fennálló tévhitek eloszlatása. A revizionista történetszemlélet egyik oszlopos képviselőjeként Corrigan szembefordul John Keegannel és a klasszikus nézettel, mely szerint az első világháború elkerülhető és szükségtelen vérontás volt, amelyben „szamarak vezettek oroszlánokat". A szerző a forrásokhoz szigorúan ragaszkodva számol le olyan közszájon forgó tévedésekkel, mint például a gáztámadások tömeges halált okozó hatásai, vagy hogy az amerikai hadsereg haszontalan lett volna a nyugati fronton. A korábbi, hagyományosnak nevezhető narratívákkal szembeforduló művek sorában mindenképp meg kell említeni Christopher Clarke The Sleepwalkers (Az alvajárók) című 2014-es munkáját.7 A kötet a háború kitöréséhez vezető okokat, eseményeket és szövetségrendszereket elemzi, miközben a főbb résztvevő hatalmak külpolitikai lépéseit és döntéshozatali mechanizmusait is részletesen bemutatja. Konklúzióiban rámutat, hogy a világháború kitörésének előidézése nem írható egyetlen ország politikai döntéshozóinak számlájára. Megközelítésében a klasszikus realizmus emberi természettel kapcsolatos felfogása köszön viszsza, hiszen elveti a gazdasági és politikai automatizmusokra alapozó magyarázatot, és az emberi tényezőt nevezi meg a nagy háború kitöréséhez vezető ok-okozati fejtegetés kulcsaként.

5 R. J. Q. Adams (ed.), The Great War, 1914-1918. Essays on the Military, Political, and Social History of the First World War (London, 1990). 195. p.

6 Gordon Corrigan, Mud, Blood, and Poppycock: Britain and the First World War (London, 2003). 432 p.

7 Christopher Clarke: The Sleepwalkers: How Europe Went to War in 1914 (London, 2014). 736 p. Magyar kiadás: Christopher Clarke: Alvajárók. Hogyan menetelt Európa 1914-ben a háború felé (Budapest, 2015). 712 p. 
Egyetlen első világháborús historiográfiai felsorolásból sem maradhat ki a szintén brit hadtörténész, Hew Strachan és munkássága. Strachan is megírta a maga első világháborús szintézisét, ami 2004-ben jelent meg. ${ }^{8}$ A kötet kiváló összefoglalója a háborúhoz vezető okoknak, a kitörése körüli eseményeknek, illetve a frontokon zajló harci cselekményeknek és a következményeknek. Keeganhez képest előnye, hogy kiegyensúlyozottabban foglalkozik a különböző frontokkal, nem helyez eltúlzottan nagy hangsúlyt a franciaországi eseményekre. Strachan emellett több munkában is foglalkozik a nagy háború egyes aspektusaival. Külön kötetben foglalkozott a háború pénzügyi hátterével, ${ }^{9}$ de önálló könyvet szentelt például az afrikai hadi eseményeknek is. ${ }^{10} \mathrm{Hew}$ Strachan részt vett abban a 2003-as vállalkozásban is, melynek gyümölcse a The First World War: The War to End All Wars (Az első világháború: A háború, amely véget vet minden háborúnak) című, szintén átfogó, összefoglaló mü. ${ }^{11}$ Ebben a négy első világháborús brit "nagyágyú", Strachan mellett Peter Simkins, Geoffrey Jukes és Michael Hickey közremüködésével készült kötetben a háború egy "frissebb", modernebb áttekintését kívánják adni rengeteg levélből, naplóból, jegyzőkönyvből vett idézet segítségével. A könyv nem csak a szakmának szól, célja, hogy testközelbe hozza az átlagolvasónak is a frontkatonák és a civilek mindennapi életét, gondolatait.

Általánosságban elmondható, hogy a brit első világháborús hadtörténetírást erős nyugatifront-központúság jellemzi. Erre maguk az angol hadtörténészek is ráéreztek, ezért az utóbbi évtizedekben arra is igyekeztek külön hangsúlyt fektetni, hogy a háború más hadszíntereire fókuszáló kutatásoknak is teret adjanak. Jó példa erre a már említett Hew Strachan Afrika-témájú kötete, de más kiváló munkák is születtek az utóbbi évek során. A teljesség igénye nélkül megemlítendő például a Jonathan Krause szerkesztői munkáját dicsérő The Greater War címü könyv..$^{12} \mathrm{~A}$ kötetben megjelent tanulmányok nemcsak angol, hanem francia, olasz és amerikai szempontokból is közelítenek a háború bizonyos hadjárataihoz. A probléma viszont az, hogy bár a kötet kilép az angolközpontúság béklyóiból, de csak más antanthatalmak szempontjainak megismeréséig merészkedik. Hasonló, szintén szűkebb hadszíntérre fókuszáló mú Edmund James Yorke 2015-ben megjelent Britain, Northern Rhodesia and the First World War címü kötete..$^{13}$ Ebben a szerző mélyreható elemzést ad az afrikai gyarmat, Észak-Rodézia (ma Zambia) helyzetéről a háború előtt és alatt. A térség fekete

8 Hew Strachan: The First World War (London, 2004). 385 p.

9 Hew Strachan: Financing the First World War (London, 1980). 280 p.

10 Hew Strachan: The First World War in Africa (London, 2004). 236 p.

11 Peter Simkins-Geoffrey Jukes-Michael Hickey-Hew Strachan, The First World War: The War to End All Wars (London, 2003). 351 p.

12 Jonathan Krause, The Greater War. Other Combanants and Other Fronts, 1914-1918 (London, 2014). 272 p.

13 Edmund James Yorke, Britain, Northern Rhodesia and the First World War. Forgotten Colonial Crisis (London, 2015). 337 p. 
lakossága is kivette részét a „fehér ember háborújából” a britek oldalán. A kötet bemutatja a térség gazdasági és társadalmi viszonyait, a brit gyarmati irányítás nehézségeit, a háború kitörését és a sorozás helyi nehézségeit, valamint a gyarmati státusz újrastrukturálódását a háborút követő években. Az olasz front eseményeit feldolgozó amerikai szakirodalomból kiemelkedik például G. Irving Root Battles in the Alps (Csaták az Alpokban) című kötete. ${ }^{14} \mathrm{~A}$ munka átfogó képed ad az amerikai olvasóközönség előtt viszonylag ismeretlen olasz frontról, jóval több azonban, mint a csaták egyszerű leírása. Röviden bemutatja az olasz egység létrejöttét, majd röviden ismerteti Olaszország történetét a háborúig. Foglalkozik az 1915-ös hadba lépéshez vezető háborús propagandával is, ami segít perspektívába helyezni a hármas szövetség olasz elárulását is. A kötet sok fontos szakirodalmi művet használ az olasz háborús részvétel ismertetése során, ez is adja igazi értékét - nem tesz hozzá a téma jobb megismeréséhez, de átfogó összefoglalást tud nyújtani róla. Több illusztrációval (térképek, korabeli fotók és dokumentumok) és tömörebb információhalmazzal, igen izgalmas módon foglalja össze az olasz front történéseit a Battleground Europe címú sorozatban megjelent Touring the Italian Front 1917-1919 (Az olasz front bejárása) című könyv..$^{15}$ A keleti front eseményeiről még 1998-ban jelent meg Norman Stone skót történész összefoglaló műve, a The Eastern Front 19141917,16 aminél máig nem született alaposabb, egyben pedig olvasmányosabb áttekintés az angolszász háborús historiográfiában. Az orvosi végzettségű, a brit hadseregben katonaorvosként is szolgált Prit Buttar rendszeresen ír remek könyveket a keleti front témájában, de ezek is inkább a népszerű ismeretterjesztő kategóriába tartoznak, nem szigorúan vett szakmai kötetek. Ettől függetlenül igen értékes művekről van szó, hiszen minőségi olvasmányt nyújtanak az angol anyanyelvű olvasóknak a keleti front eseményeiről. ${ }^{17}$

A nagy átfogó, a fronton zajló eseményeket tárgyaló vagy összefoglaló múvek mellett szép számmal születtek a háború egy-egy szakaszára, fegyvernemeire fókuszáló munkák, de ezredtörténetek vagy más, kisebb alakulatok történetei is színesítették a nagy háború szakirodalmát. Érdekes például a brit Andrew P. Hyde munkája, aki az Anglia ellen indított német bombázások történetét kutatta és írta meg The First Blitz (Az első villám) címmel 2002-ben. ${ }^{18}$ Hasonló témájú Neil Storey, több nagy sikerü történelmi ismeretterjesztő könyv szerzőjének Zeppelin Blitz címü kötete. ${ }^{19} \mathrm{~A}$ könyv az első részletes ismertetése a

14 G. Irving Root, Battles in the Alps - A History of the Italian Front of the First World War (Baltimore, 2008).

15 Francis Mackay, Touring the Italian Front 1917-1919 (South Yorkshire, 2002). 177 p.

16 Norman Stone, The Eastern Front 1914-1917 (London, 1998). 352 p.

17 Például Prit Buttar, The Splintered Empires: The Eastern Front 1917-21 (London, 2017). 480 p.; vagy Prit Buttar, Russia's Last Gasp: The Eastern Front 1916-1917 (London, 2016). 498 p.

18 Andrew P. Hyde, The First Blitz: The German Bomber Campaign Against Britain in the First World War (London, 2002).

19 Neil Storey, Zeppelin Blitz: The German Air Raids on Great Britain during the First World War (London, 2015). 352 p. 
Nagy-Britannia ellen indított német léghajótámadásoknak, melyek kissé didaktikusan, ugyanakkor praktikusan használható módon éves bontásban, csatáról csatára kerülnek bemutatásra. Storey alapos primerforrás-kutatást végzett, az eseményeket a korabeli hivatalos katonai jelentések, szemtanúk leírásai és sajtóanyagok alapján rekonstruálja. Jellegében és alaposságában hasonló a David Fletcher által szerkesztett Tanks and Trenches (Tankok és lövészárkok) címü kötet, amely "első kézből” számol be a harckocsi-hadviselésről és a harckocsik harcászati szerepéről az első világháborúban. ${ }^{20}$ A gazdagon illusztrált könyvben az angliai Dorsetben található Tank Museum primer forrásanyaga alapján kapunk átfogó képet a harckocsik szerepéről a nyugati fronton, mégpedig az ütközetekben részt vett katonák személyes beszámolói alapján, kronologikus elrendezésben. Közös jellemzője az itt említett néhány kötetnek, hogy külalakjukban a "népszerű történelem”, azaz a tudományos ismeretterjesztés műfajához sorolhatná őket az avatatlan szem, tartalmukat tekintve azonban teljes mértékben tudományos igényességú, széles primer forrásbázisra alapozó munkákról van szó. Emiatt is említendő ugyanitt a Mapping the First World War (Az első világháború feltérképezése) címú könyv. ${ }^{21}$ Az Imperial War Museum gondos felügyelete mellett készült kötet tulajdonképpen egy első világháborús atlasz, ami több száz korabeli térképet és fotót kombinál a történészi magyarázattal és a résztvevők visszaemlékezéseiből vett idézetekkel.

Amint az eddig elmondottakból talán látható, a brit és az amerikai történetírásban már a 2000-es évek előtt egyaránt megjelent a puszta katonai eseménytörténeti megközelítés meghaladásának igénye. Az új évezred eddigi két évtizedének folyamán a fiatalabb történészgenerációk tagjai ennek megfelelően a "klasszikus" hadtörténeti megközelítéseket meghaladó múveket próbáltak meg alkotni, más struktúrákat, újabb és újabb nézőpontokat vontak be kutatásaikba, így próbálva újat mutatni, hozzátenni valamit a már meglévő, így sem kicsiny historiográfiai korpuszhoz. A szintén brit Adrian Gregory 2014-es munkája22 vagy éppen Paul Cornish 2017-es műve ${ }^{23}$ épp ilyen megközelítésekkel kísérletezik. Előbbi a világháború „népek háborúja” jellegére helyezi a hangsúlyt. Ennek megfelelően a hétköznapi problémákkal is igyekszik mélységükben foglalkozni, úgymint az utánpótlás megszervezése, a katonák - és a hátország - élelmezése, a fegyvergyártás és -szállítás kérdései vagy éppen a háborúról való méltó megemlékezés módjai. Gregory kiemeli, hogy a hivatásos történészek gyakran kissé lenézően viszonyulnak a „lelkes amatőrök" munkájához, pedig több tízezernyi összegyűjtött forrás: fotók, levelek, korabeli relikviák, fegyverek porosodnak kihasználatlanul ilyen lelkes magángyűjtők birtokában, amit a megfelelő hozzá-

20 David Fletcher, Tanks and Trenches: First Hand Accounts of Tank Warfare in the First World War (London: The History Press, 2009). 192 p.

21 Peter Chasseaud, Mapping the First World War: The Great War through Maps from 19141918 (London: HarperCollins, 2013). 305 p.

22 Adrian Gregory, A War of Peoples 1914-1919 (Oxford, 2014). 217 p.

23 Paul Cornish, The First World War Retold (London, 2017). 256 p. 
állással a szakma nagy sikerrel aknázhatna ki. Kötetében ő maga is épít ilyen jellegű gyűjteményekre. Az utóbbi kötet, Paul Cornish tollából - ahogy címében is utal rá - a háború újra-elmesélésére vállalkozik, hogy a résztvevők, illetve a kortársak szemszögéből láttassa olvasóival a nagy háborút. Olyan rendszeresen ismételt kérdésekre keresi a választ, mint hogy mi okozta a háború kitörését, miért húzódott éveken keresztül, milyen okok vezettek a győzelemhez, illetve a vereséghez, és mi történt utána a világpolitika színpadán. Mindezt azonban végig a kortársak szemszögéből teszi, úgy ábrázolva az eseményeket, ahogyan azok a korszakban élők szeme előtt bontakoztak ki. Tekintve, hogy a kötet egy centenáriumi kiállítást kísérő kiadványként jelent meg, tele van illusztrációkkal (korabeli propagandaplakátok, egyenruhák, fotók, fegyverek stb.), amelyeken keresztül Cornish végigvezeti olvasóit a háború eseménytörténetén.

Még az új évezred elején, 2005-ben egy széles körű együttműködés eredményeképpen jelent meg a Warfare and Belligerence (Hadászat és hadviselés/háborúskodás) című szerkesztett kötet, ami kitűnő összefoglalóját nyújtja a nagy háború kutatási lehetőségeinek. ${ }^{24}$ A 14 fejezet mindegyikét egy-egy tapasztalt kutató írta. Az írások olyan témaköröket járnak körül, mint az angliai vidéki közösségek háború utáni helyzete, a hadifogoly-szállítás és a háborús kultúra fejlődése, az olasz hadsereg fegyelmezési technikái, az angol és német tábori lelkészek életrajzai vagy éppen a háború alatti tudományos élet. A továbbiakban témakörönkénti bontásban vizsgálom a brit és amerikai hadtörténetírás első világháború témakörével kapcsolatos főbb csapásirányait az elmúlt két évtizedből. Mielőtt azonban ebbe belevágnék, érdemes szót ejteni néhány, a nagy háború kutatásának szentelt kiadványsorozatról, amelyek kötetei között számos, a következő oldalakon ismertetett mű is napvilágot látott. Anglia ebben a tekintetben (is) élen jár. A Palgrave Macmillan Kiadó tevékenysége első helyen említendő. A kiadónak több kiváló hadtörténeti sorozata is van, melyekben szép számmal akadnak az első világháborúval foglalkozó, egészen remek kiadványok. Az amerikai Ashgate Kiadó szintén rendkívül igényes sorozatot indított "Studies in First World War History" címmel. Ebben a sorozatban olyan monográfiák megjelentetését tűzték ki célul, amelyek a nagy háború korábban nem vizsgált vagy széles körben nem ismert aspektusaival foglalkoznak. Emellett újonnan feltárt források alapján készült, egészen új eredményekre támaszkodó művek is megjelennek a sorozatban. Nem kimondottan az első világháborúra fókuszál, de sok kiváló nagy háborús munkának teret ad a már említett Texas A\&M University hadtörténelem-sorozata, a Military History Series. A sorozat köteteinek szerzői elsősorban az egyetem történészműhelyének munkatársai (állandó vagy vendégoktatók), de az Egyesült Államok számos más egyetemének történészei is publikáltak már itt kiváló monográfiákat. Közismert és méltán népszerű az Osprey Publishing Kiadó több száz kötetet számláló hadtörténeti és haditechnikai sorozata, amelyben szép számmal talál-

24 Pierre Purseigle (ed.), Warfare and Belligerence. Perspectives in First World War Studies. (Boston, 2005). 418 p. 
hatók első világháborús témájú müvek is. A nagy háborút négy kötetben dolgozták fel a sorozatban 2002-2003-ban: az első a keleti fronttal foglalkozik, a második és harmadik a nyugati front eseményeit dolgozza fel, a negyedik pedig a Földközi-tenger térségére fókuszál. ${ }^{25}$ Az Osprey Military Seriesben ugyan általában vékonyabb, sok színes illusztrációval ellátott ismeretterjesztő könyvek jelennek meg, de szakszerü rövid összefoglalását adják az adott témakörnek, a szerzők között pedig szakavatott, tapasztalt történészeket találunk.

\section{Gazdaság- és társadalomtörténeti megközelítések}

A háború gazdasági hátterével kapcsolatban kiváló munkák születtek az új évezred első éveiben. A háború társadalomtörténeti megközelítésének alapmúve az A Nation in Arms (Egy nemzet fegyverben) című 1985-ös kötet, amelyben több neves brit és amerikai nagyháború-kutató (pl. Jay Winter) írása is megjelent. ${ }^{26}$ A fejezetek - amellett, hogy a legalapvetőbb társadalomtörténeti megközelítésekkel foglalkoznak - alapot biztosítottak a későbbi kutatások számára is, amelyek ebből kiindulva egész köteteket, kötetsorozatokat megtöltő munkákká nőtték ki magukat. Ezek közül néhány izgalmasabb témákat boncolgató müvet emelnék ki, a háborút klasszikus gazdaságtörténeti szempontokból újra elmesélő munkák említésétől itt eltekintenék. Érdekes lehet azonban kiemelni Martin Horn Britain, France, and the Financing of the First World War (Britannia, Franciaország és az első világháború finanszírozása) címü kötetét, ${ }^{27}$ ami az antanthatalmak finanszírozási problémáinak összetettségére alapos kutatásokra építve világít rá. Martin Horn címével ellentétben a könyv nem szorítkozik a brit és a francia gazdasági helyzet elemzésére - bár ez a két ország valóban jóval nagyobb hangsúlyt kap -, hanem az Egyesült Államok pénzügyi viszonyaiba is betekintést kapunk, emellett külön fejezet foglalkozik a brit-amerikai gazdasági kapcsolatrendszerrel is.

A társadalomtörténeti megközelítést illetően nincs hiány a minőségi munkákban. Ennek már az elmúlt évszázad derekán is volt úttörője Arthur Marwick személyében, akinek The Deluge (Az önönvíz) című szerkesztett kötete 1965-ből azóta a műfaj klasszikusává nemesült, melyet a Palgrave Macmillan Kiadó kissé bővített változatban 1991-ben újra kiadott. ${ }^{28}$ Ebben helyet kapott a háború kez-

25 Geoffrey Jukes, The First World War 1: The Eastern Front 1914-1918 (London, 2002). 92 p.; Peter Simkins, The First World War 2: The Western Front 1914-1916 (London, 2003). 94 p.; Peter Simkins, The First World War 3: The Western Front 1917-1918 (London, 2003). 94 p; Michael Hickey, The First World War 4: The Mediterranean Front: 1914-1923 (London, 2003). 94 p.

26 Ian Frederick William Beckett - Keith Simpson, A Nation in Arms: A Social Study of the British Army in the First World War (Manchester, 1985). 276 p.

27 Martin Horn, Britain, France, and the Financing of the First World War (London, 2002). 251 p.

28 Arthur Marwick (ed.): The Deluge. British Society and the First World War. London, UK. 1991. 376 p. 
deti szakaszát övező fellelkesült állapottól a társadalom teljes apátiába süllyedéséig szinte minden jelentősebb hétköznapi faktor: az üzleti élet, a társadalmi morál és a viselkedési normák, a szórakozás és az alkoholfogyasztás alakulása vagy éppen a tudományos élet a háború éveiben. Az alapmúnek számító kötet egyfajta szellemi örököseként 2008-ban jelent meg a már szintén említett brit Adrian Gregory The Last Great War: British Society and the First World War (Az utolsó nagy háború: a brit társadalom és az első világháború) című monográfiája, ${ }^{29}$ ami a brit társadalom háborús tapasztalatával foglalkozik, nagy hangsúlyt helyezve a háború által a társadalomra gyakorolt hatások ismertetésére.

A társadalomtörténeti megközelítések közé tartozik a tisztikar és a legénység viszonyrendszerét elemző, 2000-ben megjelent kötet, a Leadership in the Trenches (Vezetés a lövészárkokban). ${ }^{30} \mathrm{~A}$ jól felépített, alaposan dokumentált munka bemutatja az angol tisztek kiképzésének menetét és felkészítésüket a különböző fegyelmi és társasági problémák kezelésére. Elemzi a tiszt-katona viszonyrendszert az 1914-et megelőző bő egy évtizedben, majd - a kötet legizgalmasabb részeként - külön-külön fejezetekben jeleníti meg a nagy háború alatti tiszt-katona viszonyt a tisztek és a beosztottak szemszögéből. Szintén nagyon érdekes a fegyelemről és a morálról szóló fejezet. Mindezt kiegészíti egy összehasonlító fejezet, melyben a szerző összeveti az eredményeket más hadseregek (Ausztrália, Kanada és Franciaország) hasonló tapasztalataival.

Szintén társadalomtörténeti vizeken evez az olasz-amerikai Christopher Capozzola Uncle Sam Wants You (Uncle Sam téged akar) című 2008-as munkája, mely az Oxford University Press gondozásában jelent meg. ${ }^{31} \mathrm{~A}$ kötet hat fejezeten keresztül vezeti végig az olvasót az amerikai hadi gépezet egyénre és társadalomra gyakorolt hatásain a hadüzenettől és a Selective Service rendszerének kiépülésétől kezdve a leszerelésig. Kiemelten foglalkozik az önkéntesek, a nők, a hátországban tevékenykedő polgári szolgálatosok és tartalékosok, illetve e sorok szerzője saját kutatásának szempontjából a legfontosabb csoport, az ellenséges idegenek helyzetével is. Nem kifejezetten az első világháborúra fókuszál, de szintén az amerikai hátországi kutatások színfoltjai közé tartozik Leslie A. Hahner To Become an American (Amerikaivá válni) címü könyve. ${ }^{32} \mathrm{~A}$ kötet az amerikanizálás és az ezzel kapcsolatos kormányzati intézkedések történetét mutatja be az első világháború és az 1920-as évek idején. Foglalkozik az asszimiláció nehézségeivel a sokszínű bevándorlóközösségek esetében, a szövetségi kormány különböző vizuális és retorikai módszerekkel dolgozó amerikanizálási törekvéseivel (kampányaival) és ezek nehézségeivel is. Érdekes, hogy

29 Adrian Gregory: The Last Great War: British Society and the First World War. (Cambridge, UK. 2008.) 364 p.

30 G. D. Sheffield, Leadership in the Trenches: Officer-Man Relations, Morale and Discipline in the British Army in the Era of the First World War (London, 2000). 270 p.

31 Christopher Capozzola, Uncle Sam Wants You: World War I and the Making of the Modern American Citizen (New York, 2008). 334 p.

32 Leslie A. Hahner, To Become an American. Immigrants and Americanization Campaigns of the Early Twentieth Century (East Lansing, 2017). 282 p. 
a háború alatt, illetve az azt követő években még a tipikus amerikai utcaképek is az amerikanizálási kampányok eszközévé váltak. A kötetről a Klió folyóiratban jelent meg recenzió Rakita Eszter tollából. ${ }^{33}$

Az amerikai egyetemek között élen jár a hadtörténeti kutatásokban a Texas A\&M University történészműhelye. Az egyetem Történelem Tanszékének Military History Series című sorozatában eddig közel 150 kiemelkedő minőségü monográfia jelent meg, melyek között a 2000-es évek folyamán néhány első világháborús témájú kötet is napvilágot látott. A nagy háború kutatásában első helyen említendő Nancy Gentile Ford professzorasszony, aki két fontos, hiánypótló kötettel, az Americans All! Foreign-born Soldiers in World War ${ }^{34}$ (Mind amerikaiak! Idegenben született katonák az I. világháborúban), illetve a The Great War and America: Civil-Military Relations During World War ${ }^{35}$ (A Nagy háború és Amerika: civil-katonai kapcsolatok az I. világháború alatt) címü rövid, de annál informatívabb művel járult hozzá a háború társadalomtörténeti, illetve kisebbségtörténeti megközelítésű irodalmához. Utóbbi egy érdekes, sok szempontból vizsgálódó, fontos kérdéseket felvető áttekintése az amerikai hátország eseményeinek és az egyes társadalmi rétegek háborús élményeinek. Az Americans All pedig egy igen alapos mü, ami az amerikai hadsereg nemzeti sokszínúségét, a Selective Service rendszerének kiépítését és a sorozás menetét tárgyalja kimerítően. A kötetből arra is fény derül, hogy milyen nehézségek adódtak a nyelvi és kulturális eltérésekből, és hogy a War Department milyen lépéseket tett ezek kiküszöbölésére. Amint azt a kötet címe is mutatja, Ford elsődlegesen azt hangsúlyozza, hogy a számos különböző nemzetiségű, különböző országokból érkezett bevándorló végül a közös háborús élmény révén egységessé tudott válni, azaz mind amerikaivá lett. Ford nagy hangsúlyt helyez a beilleszkedés elősegítésére és a hadseregen belüli nemzetiségi összetűzések kiküszöbölésére tett állami intézkedések (pl. Camp Gordon Plan) bemutatására.

Az amerikai hadba lépés megszokott narratívájának „állóvizét” Michael S. Neiberg kavarta fel 2016-ban megjelent The Path to War (Út a háborúba) című könyvével, ${ }^{36}$ melyről e tanulmány szerzője közölt ismertetést a Klió című folyóiratban. ${ }^{37}$ Ebben a kötetben a szerző alapvető állítása az, hogy a közkeletű véleménnyel ellentétben az első világháborúba való belépéskor az amerikaiak nem pusztán a propaganda áldozatai vagy egy messiáshajlamú elnök valamiféle vak követői voltak, hanem nagyon is tudatosan döntöttek a háborús részvétel

33 Rakita Eszter, „Hogyan legyünk amerikaiak?”, Klió: Történelmi Szemléző Folyóirat 2020/4. 65-70.

34 Nancy Gentile Ford, Americans All! Foreign-born Soldiers in World War I (College Station, 2001). 194 p.

35 Nancy Gentile Ford, The Great War and America: Civil-Military Relations During World War I (Westport, 2008). 193 p.

36 Michael S. Neiberg, The Path to War. How the First World War Created Modern America (New York, 2016). 313. p.

37 Ambrus László, „Az első világháború és a modern Egyesült Államok születése”, Klió: Történelmi Szemléző Folyóirat 2019/1. 60-67. 
támogatása mellett - még ha ezt azért is tették, mert úgy érezték, más lehetőség nem állt rendelkezésükre. A kötet széles sajtóanyagbázisra és levéltári forrásokra támaszkodva, nagy szakmai alapossággal és olvasmányos stílusban járja körül az amerikai hadba lépés társadalom- és eszmetörténeti kérdéseit.

A hadsereg egy szűk közösségét, a tábori lelkészséget vizsgálja Michael Snape és Edward Madigan, illetve tíz szerzőtársuk a The Clergy in Khaki (A klérus egyenruhában) című szerkesztett kötetben. ${ }^{38} \mathrm{~A}$ brit tábornokokhoz hasonlóan a tábori lelkészekkel is sokáig igen mostohán bánt az angol történetírás. A kötetben közreműködő szerzők kimerítően tárják fel a brit tábori lelkészet történetének különböző aspektusait, köztük a katolikus, kálvinista, illetve persze az anglikán lelkészek háborús erőfeszítéseit, szolgálatuk bürokráciai hátterét, a Vatikán beleszólását a tábori lelkészek kijelölésébe és az intézmény háború utáni utóéletének alakulását. A háború magyar historiográfiájában egyedülállóan Stencinger Norbert dolgozta fel a Magyar Királyi Honvédség tábori lelkész szolgálatának történetét - igen alaposan - 2012-es doktori disszertációjában. ${ }^{39}$ Az anyag kötetben még sajnos nem jelent meg.

\section{Múvészettörténeti megközelítések: irodalom, képzőművészet és háború}

Az elmúlt két évtizedben jeles példái születtek a háborúhoz különféle múvészettörténeti szempontból közelítő kutatásoknak. Ezek azonban nem korlátozódtak kizárólag a hadtörténeti irodalomban már szokványosnak tekinthető háborús propagandaposzterek és a katonadalok tanulmányozására. Érdekes példa Susanne Christine Puissant Irony and the Poetry of the First World War (Irónia és költészet az első világháborúban) című 2009-es munkája. ${ }^{40} \mathrm{Az}$ irodalomtudomány és a történettudomány módszereit ötvöző kötet a frontvonalak mentén született angol nyelvű költemények szövegeit elemzi, és fedez fel bennük újabb és újabb jelentésrétegeket. A versek tematikája igen széles skálán mozog: a mindennapok eseményei, a háború végéről álmodozás, illetve az ellenség gúnyolása mellett megjelennek az egyes fegyvernemeket (pl. a Royal Air Force-t) dicsőítő versek, a lövészárkok fedezékeihez írt ódák vagy éppen a szemléletes részletességű, szuronyrohamokat megidéző szonettek is. A költemények írói sokszor igen jó tollú, esetenként komoly tehetséggel megáldott amatőr költők, akik bátran alkalmazzák az irónia, a szatíra és a groteszk eszköztárát müveikben.

38 Michael Snape - Edward Madigan (eds.), The Clergy in Khaki. New Perspectives on British Army Chaplaincy in the First World War (London, 2013). 222 p.

39 Stencinger Norbert, A Magyar Királyi Honvédség tábori lelkész szolgálata 1868-1918, kiemelten az I. világháború időszakában folytatott tevékenységére. PhD-értekezés (Budapest, 2012).

40 Susanne Christine Puissant, Irony and the Poetry of the First World War (London, 2009). $202 \mathrm{p}$. 
A képzőművészet és az első világháború kapcsolatát vizsgálja a Propaganda and Hogarth's Line of Beauty in the First World War címü kötet. ${ }^{41}$ A cím William Hogarth A szépség analitikája című müvében megfogalmazott elképzelésére utal, mely szerint a legesztétikusabb vonal az S-alakú hullámvonal, annak élettel teli, figyelemfelkeltő volta miatt. A Hogarth-vonalat a 18. századtól kezdődően széles körben használták tervezésben, de olyan mű még nem született, amely a vonal háborúspropaganda-célú felhasználását elemezte volna. Georgina Williams munkája emiatt egyedülálló az első világháborúval foglalkozó szakirodalomban.

A háború zenetörténeti szempontú megközelítésének úttörője az utóbbi néhány évben Christina Gier amerikai zenetörténész, aki Singing, Soldiering, and Sheet Music in America during the First World War (Éneklés, katonáskodás és kotta Amerikában az első világháborúban) című könyvében nemcsak a katonadaloknak, de a háború idején komponált zenemüveknek a világháborúról való közgondolkodásra gyakorolt hatásait vizsgálja. ${ }^{42}$

\section{A háború „első kézből": a frontélmény megjelenítése}

Szintén a már említett Texas A\&M University hadtörténeti sorozatának kitűnő darabja az A Good Idea of Hel/43 (Egy hü kép a pokolról), ami a háborút testközelből átélt chasseur à pied, vagyis egy francia könnyűgyalogos katona levelein keresztül mutatja be a nyugati front nyers valóságát. Robert Pellissier 1882-ben született Franciaországban, 14 évesen kivándorolt az Egyesült Államokba, ahol egyetemi oktató lett, a háború kitörése után viszont hazautazott, és önként belépett a francia hadseregbe. Frontszolgálata alatt írt levelei részletes és plasztikus képet festenek a háború mindennapjairól.

Ugyancsak a frontélmény szemtanúk megszólaltatásával való érzékeltetésének vonalán halad a 2018-as Reporting the First World War in the Liminal Zone című, ismét a Palgrave Macmillan Kiadónál megjelent kötet. ${ }^{44} \mathrm{~A}$ munka jelentős primer forrásanyagot is feldolgozva brit és amerikai résztvevők naplóiból, leveleiből, visszaemlékezéseiből rekonstruál eseményeket, illetve jelenségeket. A kötet témaválasztása miatt is újszerü: középpontjában az első világháború ábrázolása áll a narratív újságírásban. Nemcsak azzal foglalkozik, hogy milyen képet festettek a háborúról a róla tudósító brit és amerikai újságírók, hanem megpróbálja az írások mögé benézve az egyéneket ért sokkhatást is

41 Georgina Williams, Propaganda and Hogarth's Line of Beauty in the First World War (London, 2016). 176 p.

42 Christina Gier, Singing, Soldiering, and Sheet Music in America during the First World War (Lanham, 2016).

43 Joshua Brow (ed.), A Good Idea of Hell: Letters from a Chasseur à Pied (College Station, 2003). 221 p.

44 Sara Pietro, Reporting the First World War in the Liminal Zone. British and American Eyewitness Accounts from the Western Front (London, 2018). 200 p. 
érzékeltetni. Az egyes fejezetek haditudósítói szemszögből mutatják be például a somme-i ütközetet, az ostrom alatt álló Párizst, a fronton szolgáló nők helyzetét vagy éppen az amerikai csapatok útját az óceánon keresztül Európa felé. Összességében a kötet érdekes szempontokat villant fel a nagy háború tanulmányozásához.

Izgalmas megközelítést hozott a brit-német szerzőpáros, Peter Doyle és Robin Schäfer közös munkája, a Fritz and Tommy 2015-ben. ${ }^{45} \mathrm{~A}$ kötetben a német katonák fronttapasztalatait jelenítik meg, párhuzamba állítva a Brit Expedíciós Erők katonáinak frontélményeivel. Az egyes csatákban való német és brit részvétel áttekintése helyett Doyle és Schäfer a közös pontokat próbálja megtalálni a két ellenséges nemzet fiainak háborús tapasztalataiban. A szerzők sok egyéb mellett a "Fritz" és "Tommy" nyelvezete közötti hasonlóságokat is vizsgálják, különös tekintettel a „trench slang” és a Soldatensprache szókincsváltozataira. A közös pontokban persze nincs hiány. Mindkét fél hasonló utat járt be: ugyanúgy nagy harci kedvvel, ideákat kergetve vonultak be, ugyanúgy borzalmakat és szenvedést éltek át, és ugyanúgy kialakult a bennük a bajtársiasság nemcsak katonatársaik, hanem a háború végéhez közeledve - a hátországtól való egyre mélyülő elidegenedés nyomán - furcsa mód az ellenség felé is. Az angol katonák szemében német ellenfeleik például így válhattak "a veszett Hunból" a háború végére "a jó öreg Gerry-vé". A szerzők ezt a folyamatot mutatják be számos újszerú és érdekes elemzési szempontot felvonultatva.

\section{Ezredtörténetek, katonaéletrajzok}

Az ezredforduló óta eltelt két évtized során szép számmal születtek a különböző alakulatok történetét a modern történettudomány eszközeivel feldolgozó munkák, és - köszönhetően a centenárium közelsége miatt fellendült intenzív forrásfeltárásnak - a tisztek, sőt gyakran egyszerű közkatonák hosszabb-rövidebb biográfiái is megszaporodtak. E munkák közül is megidézek néhány említésre méltó darabot, amelyek valami miatt kiemelendők a tengernyi szakirodalomból.

Magyar szempontból igen érdekes az Amerikai Expedíciós Haderő (American Expeditionary Forces - AEF) ohiói kiegészítésű 332. gyalogezrede. Ohio a 4. legnagyobb számú katonát kiállító állam volt az Egyesült Államokban, és több mint 73 ezer fős magyar lakosságával (New York után) a második legnagyobb magyar bevándorlókolóniát mondhatta magáénak. ${ }^{46} \mathrm{Az}$ "oroszlánok" becenevű ezred volt az egyetlen amerikai alakulat, amelyet az olasz fronton vetettek be. Itt osztrák-magyar erőkkel, többek között a 6 . hadsereggel került

45 Peter Doyle - Robin Schäfer, Fritz and Tommy. Across the Barbed Wire (London, 2015). $288 \mathrm{p}$.

46 Fourteenth Census of the United States Taken in the Year 1920. Vol. III., Population. Composition and Characteristics of the Population by States. 48. 
szembe a nagy háború utolsó napjaiban. A 332-esek soraiban magyar bevándorlócsaládok sarjai is harcoltak. Személyükben - még ha csak rövid időre is - magyarok néztek farkasszemet magyarokkal az első világháború frontvonalai mögül. Az ezred és lehetséges magyar katonáinak történetét magyar nyelven e sorok szerzőjén kívül korábban még nem jegyezte a magyar historiográfia. ${ }^{47}$ Az alakulattörténetet viszont az Egyesült Államokban feldolgozta Robert J. és Rebecca S. Dalessandro 2010-ben megjelent American Lions (Amerikai oroszlánok) című könyvében. ${ }^{48} \mathrm{~A}$ bőséges képanyaggal és rengeteg egyéb illusztrációval ellátott kötet leírja az ezred történetét az alakulástól a leszerelésig, gazdag forrásanyagra, főként az alakulat jegyzőkönyveire, illetve tiszti és altiszti egyéni beszámolókra, naplókra alapozva. Függelékében közli az alakulat teljes névsorát is századonkénti bontásban, megadva a lakóhelyeket is. A névsor a városokkal együtt jó kiindulópontként szolgál további kutakodásokhoz, az ezred tagjai személyes történeteinek feltárásához.

A modern hadtörténetírás egyik csúcsteljesítménye James Carl Nelson monográfiája az AEF 28. gyalogezrede „D” jelü századának történetéről és utóéletéről. ${ }^{49} A$ részben primer forrásokra, részben interjúkra épülő kötet olvasmányos krónikája a század fronton töltött időszakának. A narratív részeket gyakran egészíti ki párbeszédes jellegű szakaszokkal, amitől helyenként szinte regényszerűvé válik ez a nagyon is szakszerü történészi munka. A 28. gyalogezredben - bár nem a D században - egyébként magyar születésü katonák is szolgáltak, közülük négyen ( $a$ G, a K és az M századokban) fronttapasztalatokat is szereztek, ketten pedig (Max Rosenbaum és Antony Ohler) súlyos sebesüléseket is szereztek. ${ }^{50}$

Szintén James Carl Nelson munkája a Five Lieutenants címü monográfia, ${ }^{51}$ amely öt, a Harvard Egyetemen végzett, de különböző életutakat bejárt amerikai hadnagy történetét meséli el. A kötet szerzője széles és változatos forrásbázisra építve, biztos kézzel vezet végig minket az öt hadnagy történetén, időnként izgalmas, humoros, de többnyire tragikus eseményeket megjelenítve. A munka nem egyedülálló az amerikai had- és társadalomtörténet-írásban, de alaposságát és minőségét tekintve a kiemelkedő művek közé tartozik. Ezek az alacsony létszámmal dolgozó, mégis valamilyen közös szempont alapján kivá-

47 Ambrus László, „Az ohiói 332. gyalogezred és magyar származású katonái a Nagy háborúban" in Ambrus László - Rakita Eszter (szerk.) Amerikai magyarok - magyar amerikaiak. Új irányok a közös történelem kutatásában (Eger: Líceum, 2019): 101-128.

48 Robert J. Dalessandro - Rebecca S. Dalessandro, American Lions: The 332nd Infantry Regiment in Italy in World War I (Atglen, 2010).

49 James Carl Nelson, The Remains of Company D. A Story of the Great War (New York: St. Martin's Griffin, 2009). 400 p.

50 A New York State Abstracts of World War I Military Service, 1917-1919 (Adjutant General's Office. Series B0808) forráscsoport magyar vonatkozású anyagai alapján készült adatbázisból.

51 James Carl Nelson, Five Lieutenants. The Heartbreaking Story of Five Harvard Men Who Led America to Victory in World War I (New York: St Martin's Press, 2012). 
lasztott alanyokat bemutató csoportos életrajzok igen kiváló megoldások olyan esetekben, amikor egy-egy remek forrásanyag önmagában nem lenne elég önálló életrajzi kötet megírásához. A magyar történetírásban sajnos még nem széles körben nem alkalmazott ez a müfaj.

\section{Feminista megközelítések, a gender és a háború}

A nőtörténet, illetve a történelmi események női szempontú megközelítése az utóbbi évtizedekben számos érdekes szemponttal gazdagította a történettudományt. Nincs ez másként az első világháború kutatásában sem. Alapvető, tematikájában irányadó műnek számít a témában a Gender and the First World War címú 2014-es tanulmánykötet, ${ }^{52}$ ami nemcsak a női szempontot emeli be a háború diskurzusába, hanem sok, a tudomány előtt korábban ismeretlen témával is foglalkozik. Ilyen téma például a tábori nővérek kárára - sok esetben saját honfitársaik által - elkövetett erőszak, a háború és az anyaság összefüggései, a frontkatonák szexuális devianciái és ezekről alkotott elképzelései vagy éppen a frontvonalakon harcoló nők háborús élményeinek feldolgozása. Az egyik fejezetben arról olvashatunk, hogy a francia gyerekek hogyan élték meg a háború időszakát. Ez utóbbi különösen értékes, tekintve, hogy a Nagy háborút a gyerekek szemszögéből igen kevesen kutatják - újabb követendő példája lehetne ez a magyar historiográfiának is.

A tábori nővérek történetével külön kötet is foglalkozik. A szintén 2014-es Veiled Warriors című monográfia ${ }^{33}$ átfogó képet ad az antanthatalmak seregei mellett szolgáló „fátyolos harcosokról". A kimerítő elemzés naplók, visszaemlékezések, jegyzőkönyvek, oral history interjúk és több száz szakirodalmi tétel alapján, igen aprólékosan dolgozza fel az elsősorban brit tábori nővérek történetét az önkéntes jelentkezéstől a leszerelésig, kitérve a világ minden táján teljesített szolgálatukra. Ugyancsak a 2014-es "termés" része a The Womens" Land Army in First World War Britain című kötet. ${ }^{54} \mathrm{~A}$ szerző, Bonnie White a WLA, azaz a Women's Land Army történetét dolgozza fel, ami - annak agrártörténeti jelentősége ellenére - igen elhanyagolt területe a brit historiográfiának. 1917 januárja és 1919 októbere között gyakorlatilag a WLA biztosította egész NagyBritannia élelmiszer-ellátását. A kötet nemcsak a WLA keletkezésének és működésének eseménytörténetét ismerteti, de agrártörténeti jelentősége mellett kultúrtörténeti fontosságát is kiemeli. A szerző szerint a szervezet nem csak az élelmiszer-termelés és a férfiak frontszolgálata által keletkezett munkaerőhiány pótlása miatt volt kiemelkedően fontos. A kötet egyik fő állítása ugyanis

52 Christa Hämmerle - Oswald Überegger - Brigitta Bader Zaar (eds.), Gender and the First World War (London, 2014). 265 p.

53 Christine E. Hallett, Veiled Warriors. Allied Nurses of the First World War (London, 2014). 359 p.

54 Bonnie White, The Womens' Land Army in First World War Britain (London, 2014). 207. p. 
az, hogy a WLA létrehozásával annak szervezői már a jövőre is gondoltak: céljuk annak elősegítése is volt, hogy a brit munkáltatók a nőkre a háború után is használható munkaerőként tekintsenek. A nagy háború kutatásába ezáltal a feminista történetszemlélet emelődik be e kötet formájában.

A Veiled Warriorshoz hasonló, bár nem olyan átfogó munka a Women in the War Zone (Nők a háborús zónában) címú kötet, amely a brit tábori kórházak világát mutatja be egyéni történeteken keresztül. ${ }^{55} \mathrm{~A}$ többségében brit nővérek - közöttük nemesi és közrendű származásúak egyaránt - a háború szinte minden frontján szolgálatot teljesítettek: kezelték a sebesülteket Belgiumban, Franciaországban, Szerbiában, Lengyelországban, Oroszországban, Egyiptomban, Törökországban, Olaszországban stb. Az ápolónők élettörténetei nemcsak önmagukban izgalmasak és tanulságosak, de rajtuk keresztül a frontok eseményei is megelevenednek. A kötet így rendhagyó módon vezeti végig az olvasót a háborún annak kitörésétől egészen a fegyverszünetig, kronológiai sorba rendezve.

A brit hadtörténetírásban viszonylag ritkának számító, külön a keleti hadszíntérre fókuszáló munkák számát gyarapítja Angela K. Smith nőtörténeti megközelítésű British Women of the Eastern Front (A keleti front brit női) címü könyve, amely a szerbés az orosz frontokon szolgálatot teljesített brit női sorsokkal foglalkozik. ${ }^{56}$ A kötet nemcsak a tábori nővérek és más, a frontokon szolgált nők történetét dolgozza fel, de külön fejezetben foglalkozik a hadifogságba esett nőkkel vagy éppen azon angol hölgyekkel is, akiknek sorsa 1917-ben Oroszországban rekedve a szocialista forradalom, majd a bolsevik hatalomátvétel eseményeivel is összefonódott.

\section{Újszerū megközelítések: nyelvészet, várostörténet, pszichológia, étkezés}

A nagy háború kutatásához nyelvészeti szemszögből közelítő vizsgálódások legfrissebb eredményeit összegezte a „Palgrave Studies in Languages at War" címü könyvsorozat kétkötetes, külön az első világháború nyelvtudományi megközelítéseinek szentelt tanulmánygyüjteménye. A Christophe Declercq és Julian Walker szerkesztésében kiadott két kötet ${ }^{57}$ a háborút nyelvészeti, nyelvtörténeti megközelítésben vizsgáló kutatók előadásaira épül, melyek az University of Antwerpen és a British Library közös szervezésű, 2014 júniusában rendezett nagyszabású Languages and the First World War címú konferenciáján

55 Anne Powell, Women in the War Zone: Hospital Service in the First World War (London, 2009). 416 p.

56 Angela K. Smith, British Women of the Eastern Front. War, Writing and Experience in Serbia and Russia, 1914-1920 (Manchester, 2016). 224 p.

57 Julian Walker - Christophe Declercq (eds.), Languages and the First World War: Communicating in a Transnational War. Palgrave-Macmillan (London, 2016). 279 p., ill. Christophe Declercq - Julian Walker (eds.), Languages and the First World War: Representation and Memory (London, 2016). 256 p. 
hangzottak el. E sorok írója, a Representation and Memory ${ }^{58}$ és a Communicating in a Transnational War címú kötetek közül az elsőről közölt ismertetést a Klió hasábjain. Előbbi a háború kutatásához és emlékezetének ápolásához kapcsolódó nyelvi, nyelvészeti problémaköröket feszegető tanulmányokat tartalmaz. Utóbbi kötet pedig a soknemzetiségü, szövetségi rendszerekben harcoló hadseregek kommunikációs nehézségeit körüljáró munkákat gyűjtötte egybe. Mindkét kötetre jellemző, hogy a szerzők alapos, több éven (akár évtizeden) át zajló kutatómunka eredményeit összegzik terjedelmes tanulmányaikban.

A témakörhöz egyébként már magyarországi kiadású tanulmánykötet is hozzátett. A L'Harmattan Kiadónál 2015-ben, Z. Karvalics László szerkesztői munkájának köszönhetően megjelent Information History of the First World War (Az első világháború információtörténete) című kötet tíz tanulmánya izgalmas témákat jár körül a háborús propagandától az ezredek közötti kommunikáción át a harctéri szlengig. ${ }^{59} \mathrm{~A}$ nemzetközi szerzőgárda tagjai között magyar, angol, amerikai, brazil, olasz és kínai kutatókat is találunk, remek tanulmányt írt például az előzőekben tárgyalt kötetek egyik szerkesztője, az angol Julian Walker is.

A háború várostörténeti vonatkozásai az Egyesült Államokban is izgalmas kutatási lehetőségeket rejtenek. Az Ashgate Kiadó "Studies in First World War History” sorozatának részeként 2014-ben megjelent New York and the First World War címü munka ${ }^{60}$ például New York City társadalmi szerkezetét (és városszerkezetét), illetve épített örökségét vizsgálja meg a háború előtt, elemzi azokat a változásokat, melyeket a nagy háború idézett elő, és összeveti a két állapotot közlekedési, lakhatási, munkahelyteremtési és még egy sor további szempont alapján.

Az első világháború azelőtt sosem látott traumát okozott, elsősorban persze a fronton harcolt katonáknak, de gyakorlatilag mindenkinek, akit bármilyen formában is érintett. Ennek szakmailag igényes feldolgozása a történész szakma régi feladata. Erre az igen fontos munkára két példát emelnék ki e tanulmány keretein belül a brit történetírás elmúlt húsz évéből. Az egyik Suzie Grogan Shell Shocked Britain címü, 2014-ben megjelent könyve, ${ }^{61}$ amely foglalkozik a shell shock klasszikus hatásaival, de nagyobb hangsúlyt fektet a „brit nemzet tüzérségi sokkjának" tárgyalására. A terminust igyekszik kiterjeszteni a civil világra is. Tekintve, hogy egész közösségek (falvak, városok) elveszítették fiatal férfiak ezreit, a kötet fő gondolata akörül forog, hogy az egész ország óriási sokkhatástól szenvedett még évtizedekkel a háború befejezése után is - nem csak azok a katonák, akik a lövészárkokban szenvedték végig azt. A másik ilyen témájú munka a Jason Crouthamel és Peter Leese szerkesztésében a Palgrave

58 Ambrus László, „A nyelv(ek) szerepe a Nagy Háború emlékezetében”, Klió: Történelmi Szemléző Folyóirat 2018/3. 61-68.

59 Z. Karvalics László (szerk.), Information History of the First World War (Budapest, 2015). 202 p.

60 Ross J. Wilson, New York and the First World War. Shaping an American City (New York, 2014). 259 p.

61 Suzie Grogan, Shell Shocked Britain. The First World War's Legacy for Britain's Mental Health (London, 2014). 186 p. 
Macmillan Kiadónál megjelent Psychological Trauma and the Legacies of the First World War (Pszichológiai trauma és az első világháború örökségei) című tanulmánykötet. ${ }^{62}$ A rendkívül alapos kutatásokat felvonultató kötetben brit, francia, német és amerikai történészek tanulmányai olvashatóak, amelyek ötvözik a történettudomány és a pszichológiai traumakutatás módszereit. Foglalkoznak a mentálisan tönkrement frontkatonák mellett az azok családjait ért trauma hatásaival, a különböző generációk traumái közötti hasonlóságokkal és különbségekkel, a kezelés és reintegráció problémáival, a trauma kulturális reprezentációjával és a többségi társadalom traumatizáltakhoz való viszonyulásával is. A kötet egészen rendkívüli példája a háború mentális hatásait vizsgáló kutatásoknak, csak remélhetjük, hogy egyszer napvilágra kerül egy hasonlóan alapos elemzés az Osztrák-Magyar Monarchia hadseregeivel kapcsolatban is.

Andrew Robert Shaw, a Black Adder (Fekete Vipera) címú angol komédiasorozat negyedik, az első világháborút feldolgozó évadából választott jelenet felidézésével kezdi Feeding Tommy című könyvét. ${ }^{63}$ A híres jelenetben a Tony Robinson által játszott Baldrick közlegény „Rat au Van” fogyasztását ajánlja ebédre Edmund Blackadder századosnak, akit Rowan Atkinson alakít. A százados rákérdez, hogy mi is az a "Rat au Van” nevű fogás, mire a közlegény elárulja, hogy olyan patkány, amelyet elütött egy kisteherautó („rat that's been run over by a van"). A szerző célja ezzel az idézettel rávilágítani arra, hogy legtöbben az étkezést az első világháború idején valahogy így vagy ehhez hasonlóan képzelik el. Shaw a The Royal Logistic Corps Museum levéltári anyagában végzett kutatás, illetve több tábori szakács emlékiratai, naplói és persze szakácskönyvei alapján írta meg az első világháborús brit tábori konyha hiteles történetét. A múből kiderül, hogy a lövészárkokban az étkezés jóval többet jelentett a „Rat au Van" fogyasztásánál. A gazdag fotó- és illusztrációanyagot tartalmazó kötetben különböző levesek, sültek, szószok, sütemények receptjei találhatók, tábori környezetre - és létszámra - szabva. A korabeli szakácskönyvek állatok feldolgozásához és az egyes húsfajták tartósításához is tartalmaztak útmutatót. Shaw könyve érdekes adalékkal szolgál a nagy háború mindennapjainak átfogóbb megismeréséhez. Ráadásul szakácskönyvként is kitűnően használható.

A háború utóéletével foglalkozó újabb szakirodalomból említésre érdemes - az egyébként szintén a Texas A\&M University múhelyéből kikerült - Adam R. Seipp The Ordeal of Peace című munkája. ${ }^{64}$ A kötet egy-egy brit és német példán keresztül szemlélteti a háború utáni leszerelés folyamatát és annak társadalomra és városszerkezetre gyakorolt hatásait. A szerző két egymástól történelmileg teljesen különböző települést, az észak-angliai iparvárost, Manchestert

62 Jason Crouthamel, Peter Leese (szerk.), Psychological Trauma and the Legacies of the First World War (London, 2017). 338 p.

63 Andrew Robert Shaw, Feeding Tommy. Battlefield Recipes from the First World War (Stroud, 2013). 208 p.

64 Adam R. Seipp: The Ordeal of Peace. Demobilization and the Urban Experience in Britain and Germany, 1917-1921 (Farnham, 2009). 292 p. 
és a dél-német királyi várost, Münchent választotta a kutatás tárgyául. A nyilvánvaló különbségek ellenére alkalmasak arra, hogy Seipp rajtuk keresztül szemléltesse, hogy a győztes és a vesztes hatalmak társadalma egyaránt megszenvedte a fizikai, bürokratikus és kulturális mobilizációt, amit a hosszan elhúzódó háború megkövetelt mindenkitől. A kötet kiegyensúlyozottan dolgozik a társadalomtörténet, a hadtörténet és a várostörténet sajátosságaival, átélhetővé teszi a leszerelés infrastrukturális kérdéseit, illetve a frontról hazaözönlő leszerelt katonák letelepedésének, a civil életbe visszailleszkedésének problémáit.

\section{A hátország és a kisebbségek}

Magyarországon Bihari Péter 2008-as munkája ${ }^{65}$ nagyszerű kezdeményezése volt a háború társadalomtörténeti szempontú megközelítésének, de önálló kötet formájában sajnos azóta sem akadt követője. Pedig a Magyar Királyság különböző népeinek helyzete és viszonyrendszere igen mély, részletekbe menő kutatásokra adna lehetőséget. Bár a Nagy Háború Blogon rendszeresen jelennek meg a hátország helyzetét tanulmányozó cikkek, de az ilyen jellegú vagy éppen a kisebbségek viszonyaival foglalkozó monográfiák egyelöre sajnos még hiányoznak a magyar historiográfiából.

A hátország életét bemutató munkák is bőségesen születtek az elmúlt két évtized során, közülük néhány fontosabbat kiemelni nem egyszerű feladat. 2006-ban megjelent egy kiváló gyűjtés az amerikai ABC Clio Kiadónál The Home Front Encyclopedia címmel. ${ }^{66} \mathrm{~A}$ három kötetből álló enciklopédia első két kötete a két világháborút dolgozza fel. Felosztásuk azonos: rövid bevezető után mindkét kötetben a hátországok főbb politikai és közéleti szereplőinek életrajzai következnek, majd végül maga a háborús fogalmak magyarázatait szócikkek formájában tartalmazó lexikonrész. A harmadik kötet tulajdonképpen egy szöveggyưjtemény a két világháború történetének társadalomtörténeti szempontú tanulmányozásához. Az enciklopédia mindhárom kötete kiváló segédeszköz lehet a felsőoktatás számára is.

Saját kutatásomhoz a háború etnikai, kisebbségtörténeti szempontú megközelítése áll legközelebb. Ebben a tekintetben is példaértékű módon jár elöl a brit történettudomány. Az ismert brit múvelődés- és társadalomtörténész, Panikos Panayi szerkesztésében készült, a német kisebbségek háború alatti helyzetét nagy alapossággal feldolgozó mű kitűnő példája ennek. A Germans as Minorities during the First World War (Németek kisebbségként az első világháború alatt) címú kötetben képet kapunk a mintegy négy és félmilliós német diaszpóra

65 Bihari Péter, Lövészárkok a hátországban. Középosztály, zsidókérdés, antiszemitizmus az első viláhgáború Magyarországán (Bp, 2008). 286 p.

66 James D. Ciment (ed.), The Home Front Encyclopedia. United States, Britain, and Canada in World Wars I and II, Volumes I-III (Santa Barbara, 2006). 1479 p. 
életéről a háború idején. Közöttük akadtak londoni pékek és nevelőnők, amerikai hentesek, brazíliai rakodómunkások, állami hivatalnokok a Baltikumban, ruhakereskedők vagy éppen tőkebefektetők Olaszországban. A kötet feltárja, hogy ezek a kisebb-nagyobb Auslandsdeutsche közösségek milyen mértékben, illetve milyen módon őrizték meg kulturális örökségüket, nyelvüket és összességében: identitásukat a sok különböző idegen környezetben. ${ }^{67}$ Panikos Panayi saját, német hadifoglyokkal kapcsolatos kutatási eredményeit önálló kötetében is összefoglalta Prisoners of Britain (Britannia foglyai) címmel 2012-ben. ${ }^{68}$

Egyik legfrissebb termése az első világháború kisebbségkutatásának a Palgrave Macmillan Kiadónál 2017-ben napvilágot látott kötet, ami a Minorities and the First World War (Kisebbségek és az első világháború) címet kapta. ${ }^{69} \mathrm{~A}$ könyv részletes képet ad arról, hogy milyen problémákkal néztek szembe egyes hadviselő országok kisebbségei a nagy háború alatt. Egész pontosan a következő hadviselő országokkal foglalkozik: Nagy-Britannia, Németország, Franciaország és az Oszmán Birodalom. A három nagyobb szegmensre osztott tizenegy fejezet tematikailag igen széles skálán mozog. Szó esik többek között a muzulmán vallású britekkel kapcsolatban felmerült lojalitásbeli kérdésekről, a belga menekültek problémáiról, az angliai germanofóbiáról, a törökországi örmények helyzetéről a népirtás előtt és után vagy éppen a francia gyarmatpolitikáról. Mivel a kötet az európai hadviselő országokra fókuszál, így az Egyesült Államok kisebbségei nem szerepelnek benne. A kutatás számára emiatt elsősorban módszertani szempontokból lehet igen hasznos.

Mindenképp említést érdemel David Silbey a brit munkások háborúhoz füződő viszonyát tárgyaló, The British Working Class and Enthusiasm for War 1914-1916 (A brit munkásosztály és a háború iránti lelkesedés) című munkája. ${ }^{70}$ A rövid, de alapos mű célja áttekinteni a "kékgalléros” társadalmi rétegek háború iránti lelkesedésének okait, amelyek lehetővé tették az európai államok számára, hogy totális háborúba bocsátkozzanak. A kötet bemutatja, hogyan beszéltek a brit munkások a háborúról, milyen szavakat használtak, hogyan nyilatkoztak motivációikról. A szerző igen helyesen mutat rá, hogy a hadtörténetírás mindaddig képtelen lesz feldolgozni a totális háború kialakulásának okait, amíg meg nem értjük azt a hadviselo országokban tapasztalt „kimondatlan konszenzust", amely a háború széles társadalmi támogatottsága - és például a brit önkéntesek nagy száma - mögött állt.

Fontos társadalomtörténeti kérdést feszeget - és témáját tekintve akár a nőtörténeti részbe is beilleszthető lenne - a Singled Out („Kiegyelve”) címü,

67 Panikos Panayi (ed.), Germans as Minorities during the First World War: a Global Comparative Perspective (London, 2014). 328 p.

68 Panikos Panayi, Prisoners of Britain: German Civilian and Combatant Internees during the First World War (Manchester, 2012). 342 p.

69 Hannah Ewence - Tim Grady (eds.), Minorities and the First World War. From War to Peace (London, 2017). 300 p.

70 David Silbey, The British Working Class and Enthusiasm for War, 1914-1916 (London, 2005). 189 p. 
önmeghatározása szerint inkább a szélesebb olvasóközönségnek, mint a szakmának szóló, mégis alapos kutatásra támaszkodó monográfia. ${ }^{71}$ A szerző a brit háborús emberveszteség társadalmi, demográfiai hatásait elemzi. NagyBritannia mintegy kétmillió férfit veszített el az első világháború alatt, 1921-ben Angliában és Walesben összesen 19.803.022 nő és 18.082.220 férfi élt. Erre a közel kétmillió nőre a korabeli sajtó gyakran „többletlányok” néven hivatkozott.

\section{Tovább is van...}

A tengernyi szakirodalomból több kötetnyi terjedelemben lehetne szemezgetni. A leírtakban talán sikerült egyfajta ízelítő körképet adnom az első világháború elmúlt két évtized során megjelent angol nyelvű historiográfiájának sokszínúségéről. E körkép célja nem a teljes szakirodalmi bázis bemutatása, sokkal inkább széles repertoárjának, témabeli sokszínűségének érzékeltetése volt. Az angol nyelven megjelent tengernyi szakkönyv jól mutatja, hogy még száz évvel annak lezárása után is milyen széles körű kutatási lehetőségeket rejt magában az első világháború, aminek újabb és újabb rétegei, elemei kerülnek felszínre, ahogy kutató történészek újabb generációi egyre frissebb módszerekkel és friss szempontok szerint állnak hozzá a témához. Mi lehet a tanulsága egy ilyen historiográfiai áttekintésnek egy magyar történész számára? Talán annyi, hogy az angolszász szakirodalom világába tett „kirándulás” rávilágít arra, mennyi kiaknázatlan lehetőség van még a forrásokban, és hogy mekkora terra incognita terül el még mindig a nagy háború magyarországi historiográfiája előtt.

71 Virginia Nicholson, Singled Out: How Two Million British Women Survived without Men after the First World War (New York: Oxford University Press, 2008). 328 p. 